\title{
Poverty Overcoming Problems of Russian Population
}

\author{
Karasik E.A. \\ Yurieva O.V. \\ Salyakhov E.F. \\ Chursin P.B. \\ Kazan Federal University, Institute of Management, Economics and Finance, Kazan, 420008, Russia \\ Emai:hulia_k@mail.ru
}

Doi:10.5901/mjss.2015.v6n3p736

\section{Abstract}

Article is devoted to problems of improvement of social policy in Russia, to an analysis of problems of poverty, including the working population of the Russian Federation, to a ratio of the minimum income and a living wage of the working population, social and economic consequences of crisis and ways of their overcoming from the position of poverty problems solution.

Keywords: Standard of living, quality of life, disabled people (persons with special opportunities of health), social policy, relative poverty, subjective poverty, professional rehabilitation of disabled people, population.

\section{Introduction}

The turn of the new millennium is characterized by global turn in world social and economic development. In the conditions of information society the new type of public consumption and a way of life is formed. In these conditions there is a need of a new paradigm of economic growth which demands revision not only former ideas of its factors and sources, but also formation of the value of economic growth which has to be based on essentially new approaches to definition of welfare essence, the public and individual, and also interfaced categories, first of all, such as quality of life, standard of living, poverty.

During transformation of the principles of economic interaction the considerable part of the population of Russia appeared behind line of a living wage. By different estimates, depending on methods of poverty measurement, the needy in Russia is from 30 to 60 million people [1]. To poor traditionally belong the working citizens, whose salary is lower than a living wage, pensioners, disabled people, students, large and incomplete families, refugees and immigrants, neglected children and others. Despite the fact that number of socially and economically unprotected population in Russia gradually decreases, it is impossible to speak about overcoming of a problem of poverty.

Table 1. Population with the monetary income lower than the size of a living wage and deficiency of the monetary income

\begin{tabular}{|l|c|c|c|c|c|c|c|c|}
\hline Indicators & 2006 & 2007 & 2008 & 2009 & 2010 & 2011 & 2012 & 2013 \\
\hline $\begin{array}{l}\text { Population with the monetary income lower than the size of a living wage: } \\
\text { including, }\end{array}$ & 651,9 & 519,8 & 372,6 & 328,9 & 297,5 & 268,6 & 268,8 & 223,1 \\
\hline percentage of the total number of the population & 55,3 & 44,6 & 32,3 & 28,8 & 26,2 & 23,8 & 23,9 & 19,9 \\
\hline deficiency of the monetary income (billion rubles) & 5,2 & 4,9 & 3,4 & 3,3 & 3,4 & 3,4 & 3,3 & 3,2 \\
\hline percentage of the total amount of the monetary income of the population & 18,2 & 11,6 & 6,2 & 5,0 & 4,2 & 3,5 & 3,6 & 2,6 \\
\hline
\end{tabular}

Data from the tables shows the decrease of the number of Russian citizens with the income, which is insufficient for fullfledged, qualitative life, however the number of the poor population continues to remain essential.

\section{Theory}

Poverty conducts to reduction of birth rate and increase of mortality, reduction of number of indigenous people, 
degradation and depopulation, disintegration of families, deterioration of health of the population (growth of mental diseases, life expectancy reduction)which, according to the conclusion of scientists, generally depends on social and economic factors.

Table 2. Main demographic indicators (average version of the forecast of the UN for Russia),1000 persons. [2]

\begin{tabular}{|l|c|c|c|c|c|c|}
\hline Main demographic indicators & $1995-2000$ & $2000-2005$ & $2005-2010$ & $2010-2015$ & $2015-2020$ & $2020-2025$ \\
\hline Average annual decline of population & -453 & -516 & -513 & -582 & -679 & -672 \\
\hline Coefficient of natural increase & $-0,49$ & $-0,5$ & $-0,42$ & $-0,42$ & $-0,5$ & $-0,5$ \\
\hline Coefficient of a migratory gain & 0,18 & 0,14 & 0,07 & 0 & 0 & 0 \\
\hline The expected duration of life, years: Men & 58,0 & 59,0 & 61,0 & 63,0 & 65,0 & 66,5 \\
\hline Women & 71,5 & 72,1 & 73,3 & 74,0 & 75,3 & 76,1 \\
\hline
\end{tabular}

The problem of poverty is so actual that allows to say that many other problems are reduced to it. Questions of demography, employment of the population, unemployment are directly connected with poverty; poverty has the most direct impact on health of the population, education level and cultures of citizens, their education, socialization and moral, poverty is one of brakes of science development. Poverty promotes a dehumanization of the human relations, rise in crime and terrorism, conducts to lowering of the level and qualities of life. It specifically influences the political relations, realization of a state policy at all levels, obviously slows down development of the market relations as in regions and in Russia in general.

It is quite obvious that a problem of reduction of poverty is not to be solved by reorganization of the sphere of distribution, increase in sale of natural raw materials, by adoption of separate programs. A problem root is in production, in the person himself. It is only possible to distribute that is created by work.

Aspiration of the state to solve a poverty problem by means of various projects and laws, including increase of a salary, without growth of labor productivity, economy of resources, improvement of quality of production, training of competitive experts, workers and managers, is not possible. The paternalism will bring and already led to a dependence: per production working in the sphere 8-10 intermediaries are necessary. Therefore other structure of society, other distribution of the busy population on branches and fields of activity, other system of training of skilled workers and transition to resource-saving technologies and modern management is necessary. Thus it is necessary to consider aging of the population - the senior generation already now makes $23,5 \%$ of population that negatively affects quality of a manpower [3].

Nowadays there is a set of conceptual approaches to definition of the category "poverty". Traditionally poverty is defined "as a state at which the household for one reason or another can't satisfy the basic needs, lacking for material resources for maintaining a way of life which in this society is characteristic" [4].

Poverty is relative concept and depends on the general standard of a standard of living in this society, it is the characteristic of an economic situation of the individual or social group at whom they can't satisfy a certain circle of the minimum requirements necessary for life, preservations of working capacity, a reproduction.

Except this basic classification of types of poverty, there are also other approaches. So, mark out primary poverty (these are the families which are in rational charge of housekeeping, but not having sufficient financial means) and secondary poverty (families which have enough financial means, but need because of irrational housekeeping). At last, there is a division into "steady" poverty (poverty "by inheritance") and "floating" (some poor individuals find opportunity to come to higher standard of living, but at the same time people with middle-income are ruined and pass into the category poor).

\section{Results}

Social policy of the last years in Russia doesn't promote the effective solution of poverty problems, instead of fighting against poverty there are offered all new techniques which are directed on poverty reduction.

At the same time, the long-term programs accepted for overcoming of the population poverty define the following reference points of social policy:

decrease the level of absolute and relative poverty (or needy part of the population), increase in middle class by 2020 to more than a half of the population;

- decrease the differentiation of the population on the level of the income (a ratio of the income of 10 percent of the richest and 10 percent of the poorest) about 16,8 times in 2007 to 12 times in 2020; 
- achievement by 2020 of an employment rate of disabled people in the Russian Federation 40 percent from total number of disabled people.

Achievement of the priorities called in federal programs is supported with a regional component. So, in the Republic of Tatarstan is accepted the Program of social formation, transport and engineering infrastructure, which is available to disabled people, which has to promote an implementation of disabled people including in feasible work.

Table 3. Results of implementation of the Program for formation of social, transport and engineering infrastructure, available to disabled people, [5]

\begin{tabular}{|l|c|c|}
\hline $\begin{array}{l}\text { Key parameters of the Available Environment Program in the Republic of } \\
\text { Tatarstan }\end{array}$ & $\begin{array}{c}\text { Results of implementation } \\
\text { of the Program in 2012. }\end{array}$ & $\begin{array}{c}\text { Expected results of } \\
\text { implementation of the } \\
\text { Program by } 2015\end{array}$ \\
\hline $\begin{array}{l}\text { share available to disabled people and other handicapped groups of the } \\
\text { population of priority objects of social, transport, engineering infrastructure in } \\
\text { total of priority objects in total of priority objects }\end{array}$ & $16,8 \%$ & $45 \%$ \\
\hline $\begin{array}{l}\text { share of rolling stock park of motor and city land electric transport of the general } \\
\text { use equipped for transportation of handicapped groups of the population in park } \\
\text { of this rolling stock }\end{array}$ & $11,4 \%$ & $16,5 \%$ \\
\hline $\begin{array}{l}\text { share of persons with limited opportunities of health and the disabled people who } \\
\text { are systematically playing physical culture and sport in the total number of this } \\
\text { category of the population }\end{array}$ & $5 \%$ & $10 \%$ \\
\hline $\begin{array}{l}\text { share of educational institutions in which is created the universal barrier-free } \\
\text { environment allowing to provide coeducation of the disabled people and persons } \\
\text { who don't have development violations in total of educational institutions }\end{array}$ & $5,5 \%$ & $20 \%$ \\
\hline $\begin{array}{l}\text { share of the disabled people who are positively estimating the level of availability } \\
\text { of priority objects and services; }\end{array}$ & $33,7 \%$ & $55 \%$ \\
\hline $\begin{array}{l}\text { share of the disabled people who are positively estimating the population relation } \\
\text { to problems of disabled people, in total of the interrogated disabled people }\end{array}$ & $33,6 \%$ & $49,6 \%$ \\
\hline
\end{tabular}

At the same time, in the context of a problem of poverty it is possible to note that results of implementation of the Program don't assume its decision, and only reduce its negative impact on society.

Irrespective of, what primary reasons of poverty, time having arisen, it starts replicating. Than the bigger percent of the population of the country is behind line or about a poverty line, it is more than subjects at this country of chances to get to "a vicious circle of poverty". After all if the considerable part of the population poor, it can't acquire goods, as a result there are no production investments that conducts to impossibility to develop economy and to raise a salary of workers. Thus, it is more difficult for country in which the considerable part of the population lives in poverty to escape from poverty.

If it is possible to speak about eradication of absolute poverty in a number of the developed countries, relative poverty will be a constant problem of any country in the near future [6].

According to various Russian sources, in 1992 - 1995 poor socially vulnerable segments of the population traditionally were the center (pensioners, disabled people, large and incomplete families with children). But by the end of the 1990th the center of gravity was displaced to the "working" poor - able-bodied citizens who gained low income and couldn't support themselves and a family. Were the main reasons for such situation the low level of salaries which isn't providing a living wage of their recipients, delays with payments, unemployment, a part-time employment, the compelled administrative holidays without providing monetary compensation, etc. In 2007 treated the needy, according to Rosstat, $65,2 \%$ of people of working-age, $21,4 \%$ of children aged till 16 years and $13,3 \%$ of elderly people. In $200961,1 \%$ poor the people of working-age including occupied in economy $-59,4 \%$. 


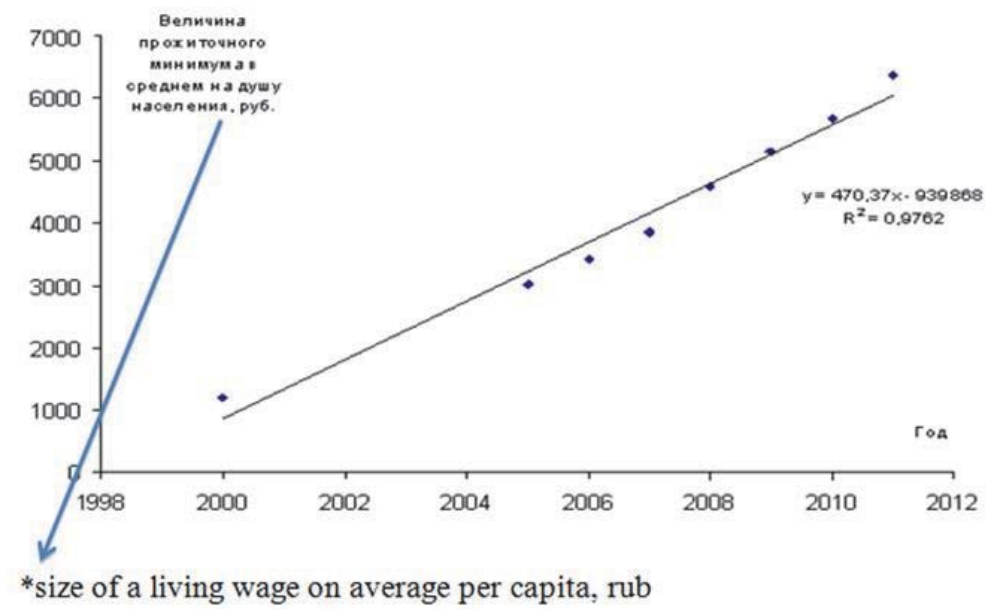

Fig. 1. Dynamics of size of a living wage in Russia

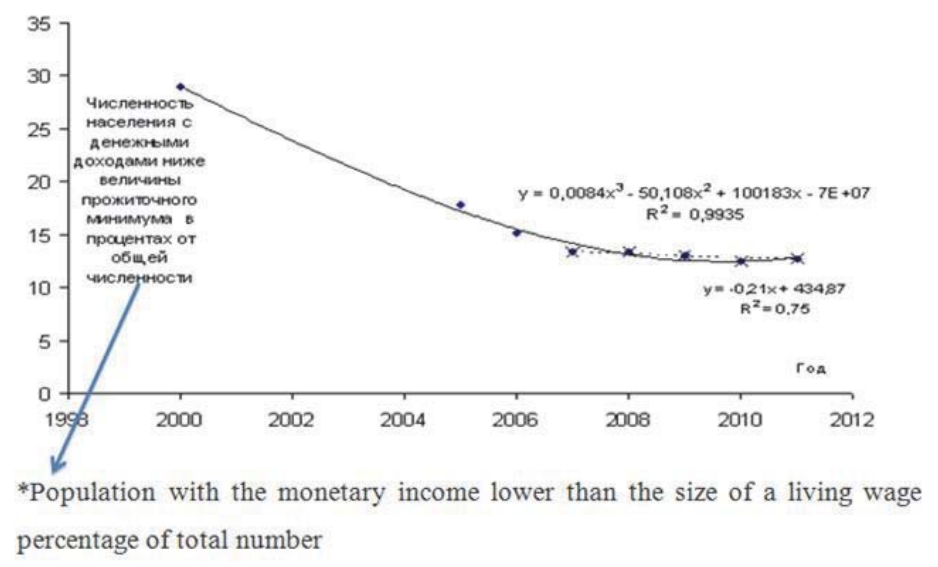

Fig. 2. Dynamics of a share of population with the monetary income lower than the size of a living wage

The model of poverty which is developed in the country, first of all, is a result of low level of the income from employment and, as a result, - through their taxation - the low level of social transfers.

Poverty in Russia possesses the peculiar feature typical for developing countries: if in the developed countries of the world poverty, as a rule, is connected with unemployment, in Russia poverty covers not only the unemployed but also much working at low-paid positions i.e. there is a certain specific phenomenon, the working poor. A phenomenon, unprecedented in the developed countries. In all normally developing countries work existence, are not always the guarantor of prosperity, the high income, but rescues from poverty. In Russia even working it is possible to stay in poverty.

The share poor in Russia makes according to different sources from one heel to one fourth all population. The main contradiction of the Russian poverty - its prevalence among the working population.

\section{Conclusion}

The working population has an income source, but has no opportunity to lead a full-fledged life. The Russian poverty, being a consequence of the low income from employment, has the able-bodied face. Such poverty has a number of consequences on a national scale: decline in quality of labor, deterioration of a demographic situation, lack of reproduction of labor. As a result, in the long term one and a half-two decades Russia is doomed to decrease in human potential, increase in number economically and politically inactive population.

Fight against poverty of the working population has the following purposes: providing to the worker and members 
of his family of living conditions to appropriate time and society to which they belong; creation of conditions for reproduction of labor; smoothing of the public response caused by sharp polarization of the income; increase of economic and political activity of the population.

In Russia there was an approach according to which at determination of level of poverty the real income of the population is compared with a living wage. At such approach are considered poor what income is lower than the size of a living wage. In our opinion, such understanding of poverty significantly displaces borders of an assessment of width of its distribution. The distorted picture of an assessment of level of the Russian poverty involves a mistake at a choice of a political policy on its overcoming. So, inevitably reduces efficiency of the measures, which are carried out in the sphere of social and economic policy.

\section{References}

Fakhrutdinova, E.,Karasik, E.,Kolesnikova, J.,Yagudin, R. Study of problems of population's poverty of Russia Mediterranean Journal of Social Sciences 20145 (18 SPEC. ISSUE), pp. 139-144

Yagudin, R. H. Health as a factor of improvement of life quality in transformational economy. - Kazan: Kazan state university, 2008. Page 49.

Safiullin L.N., Ismagilova G.N., Safiullin N.Z., Bagautdinova N.G. The development of welfare theory in conditions of changes in the quality of goods and services (2012) World Applied Sciences Journal 18, pp. 144-149.

Gataullin R., Ishmuratova V. Poverty in Russia: scales and ways of overcoming. - Ufa: East university, 2009. - page 35.5. E. Karasik, R. Yagudin, A. Leukhin and V. Zagidullina Improvement of social policy towards the disabled in the Russian Federation. Life Science Journal 2014;11(6s), p.478/

Fakhrutdinova, E., L. Safina, D. Shigapova and R. Yagudin, 2013. Legislative provision of the quality of working life in Russia. World Applied Sciences Journal, 27(13): 92-96.

Safiullin L.N., Gafurov I.R., Shaidullin R.N., Safiullin N.Z. Socio-economic development of the region and its historical and cultural heritage. Life Science Journal 2014; 11(6s): 400-404.

Gafurov I.R., Platonova O.U., Pratchenko O.V. New State Economic Policy - Cluster Policy Cluster Policy as the Factor of Innovative Development of Europe// Mediterranean Journal of Social Sciences.- Vol.5, No12, (2014)-pp.107-112.

Bagautdinova N.G., Khadiullina G.N.,. Shevko N.R, Pratchenko O.V. Condition and Development Characteristics of The Russian Market of Information Technilogies// Mediterranean Journal of Social Sciences.- Vol.5, No12, (2014)-pp.21-26.

Ismagilova G.N., Safiullin L.N., Bagautdinova N.G. Tourism development in region based on historical heritage. Life Science Journal 2014; 11(6s):363-367. 